\title{
Religiosity and Organizational Citizenship Behavior: a Study on Student Employees in South Tangerang
}

\author{
Chandra F. Arifianto ${ }^{1 *}$, Mutawali ${ }^{2}$, Heny Subekti ${ }^{3}$ \\ ${ }^{1,2}$ Department of Management, Faculty of Economy, University of Pamulang, Jl. Surya \\ Kencana No 1 South Tangerang, Indonesia \\ ${ }^{3}$ Department of Civic Education, Faculty of Teaching and Education, University of Pamulang, \\ Jl. Surya Kencana No 1 South Tangerang, Indonesia \\ *Corresponding author: \\ Email: chandrafa.spsi.mm@gmail.com
}

\begin{abstract}
.
This study explored the concept of Organizational Citizenship Behavior (OCB) in relation to student employees. The dimensions of religiosity is used as an independent variable in this study. This study expands the extant research by examining $O C B$ of student employees, where very few studies exist. For this research 174 student employees completed an online survey, where we looked to identify correlations between $O C B$ and three dimensions: participation, importance and meaning. Data collection in this study used a qustionnaire that developed a variable of religiosity totaling 9 items and variables totaling 15 items which isusing multiple linear regression. The statistically significant correlation between three of these dimensions and $O C B$ will help campusidentify and encourage OCB in their student employees. The result of study shows that there is effect of the participation dimension $(X L)$ and the meaning dimension (X3), but there is no efect of the meaning dimension $(X 3)$ on $O C B$.
\end{abstract}

Keywords: Religiosity, OCB, Student employees, participation dimension, importance dimension, meaning dimension

\section{INTRODUCTION}

The sense of ownership of an organization that refers to organizational citizenship behavior (OCB) is being explored by scholars. Behavior that consciously wants to do something in the name of the organization without reward, is something that is less common. But in fact, many are showing these things. There is link between self-satisfaction and OCB at work [1]. His research shows that the higher individual's position (as picture of satisfaction at work) has negative effect to his/her OCB. Thus, it is illustrated that job satisfaction is a very weak predictor for OCB. Whereas there is a relation between satisfaction in working with $\mathrm{OCB}$, although he states this depends on gender, age and length of work [2].

Next, research in Indonesia itself. There is an influence, both organizational commitment and job satisfaction with $\mathrm{OCB}$ on employees in a private enterprise in Yogyakarta [3]. The interested one is research using student respondents who were involved in student organizations [4]. The results also show the same thing, namely the 
influence of job satisfaction on OCB. Another reasearch also found that student employees had a high OCB towards the organization where he worked compared to the campus he studied. But what must be considered that the respondents are student employees who work part time on their campuses [5].

However, job satisfaction does not affect OCB. The behavior of being a good corporate citizens/employees (good corporate citizens), not necessarily because of employee satisfaction at work. Such behavior may be caused by other factors, such as religiosity and organizational climate. The factor of religiosity itself is the strongest factor [6].

Therefore, researchers see that there is still few literatures that analyzing religiosity behavior towards OCB. Moreover, this research uses student as respondents. Students themselves are divided into pure students who are only active on campus (studying and organizing) and student employees, who divide their time to study and working. Student employees at private universities often just study and then go home, without even being interested in being active in campus organization. Student employees have high motivation to study, but must deal with time management for lecturing and working [7]. On the other hand, students who care about campus, join the clubs on campus, take part in campus activities, and help campus friends, are the OCB forms for students [8]. For this reason, a sense of ownership of the campus will become more value for them, when able to become part of the campus. This is what is described as OCB in the student work environment.

If student employees have high OCB, lik employees, the campus will have students ith high productivity in academics, save energy resources in maintaining campus functions and coordinate the academic community easily by involving the student workers (9) event thogh they are busy with their job outside campus. On this basis, researchers believe that this study will be able to provide an overview related to OCB behavior that exists in student employees. What's more, researchers also want to see the effect of religiosity on OCB. In a country that upholds religion and is engraved in the first precepts of the state symbol, every individual of Indonesia should be able to carry out their respective religious orders in their daily lives.

Previous research conducted on students in Purwokerto, has shown that there is only one dimension that has a significant influence between religiosity and $\mathrm{OCB}$, while other dimensions (ritual, ideological, intellectual, experience) have no influence at all [10]. The same thing happened to teachers and staff in Sleman, where religiosity had no significant effect on OCB [11]. But when the employees as respondents, the research has different results. The religiosity of employees on a private enterprise in Semarang has a significant effect on OCB [12]. Even in state-owned enterprises, religiosity has an influence on OCB [13]. 


\section{Religiosity}

When discussing religiosity, of course, there are many ways of looking on it. Commonly, religiosity cannot be separated from religion [14]. There are also those who scientifically recognize religiosity in different ways. So that religiosity is closer to the beliefs and activities. Therefore, it need a single concept of religiosity itself. To measure this religiosity, many concepts have been used and the possibility of being related to one another [15].

While, this study using the religiosity approach theory which looks at religiosity in general. For this reason, There are mentions the following three dimensions to measure one's religiosity [16].

a. Participation.

It can be described as the intensity of individuals attending or attending religious services. Each region have a different intensity of activities. In Indonesia, religious activities often take place routinely and massively. Praying in congregation conducted 5 times a day is routinely carried out. Not to mention the recitation, istghosah, grand takbir to rituals that are harmonized with local culture. Other religions (Protestant, Catholic, Hindu, Buddhist and Confucian, as minority religions) also carry out their rituals freely and routinely. Because the government has guaranteed the implementation of religious activities and stated in the law, making the intensity of religious service activities is certainly strong in Indonesia. This is what further grows the seeds of mutual respect and preserves interfaith harmony. It can be described the intensity of attending religious services is so high. Religious activities themselves are the joints of individual life in Indonesia [17]. For that reason, facilities to be able to carry out religious activities are provided places of worship anywhere. Starting in cities, villages, offices, schools, even prisons. Such individuals are said to have extrinsic religiosity because they carry out ritual activities to meet their inner needs [18].

b. Importance.

Here individuals feel the need for God's presence in their lives. In their daily lives, individuals will feel that God will always watch over them so they will always be careful when they act. There are still Western societies in the US who believe in the role and intervention of God in creating the universe [19]. Therefore, they represent their gratitude with prayer and worship. Such individuals truly believe that God exists, without the need for sensory evidence. This is what shows the individual's own faith [20]. This faith is born from the existence of confidence in him on the existence of God. Attitude arises because of his faith. Then seen in the form of behavior [21]. Faith is 
what drives the individual to always be close to God and feel the need for God's presence in him. It is included as intrinsic religiosity [18].

c. Meaning.

This is the frequency which one ponders the meaning and purpose of life. Many in psychology studies show that the meaning of life is always related to the level of welfare. Individuals who have the meaning of a good life in themselves, then have the opportunity to survive longer [22]. Even more interesting when the meaning of life devided into 3 views [23]: (1) a broad sense of life and individual sense; (2) a core sense in the purpose and direction of one's life; and (3) a sense of value inherent in life and have a life worth living. While the meaning of life by students is different from the results [17], how a student when viewed by the meaning of his life in terms of religion, family, social interaction, new moments, love, emotions, and challenges, shows that the meaning of life is more towards emotional factors and social interaction. There is explained more emotional factors to how they have benefits for others, while social interaction actors lead to the ability to solve challenges [24].

\section{Organizational Citizenship Behavior (OCB)}

The concept of Organizational Citizenship Behavior (OCB) has been widely illustrated by several figures, such as: [25], [26] to [27]. Also, there has been a development in understanding problems with the OCB approach [26]. So, that it can provide conceptual understanding and differences between various forms of citizenship behavior (citizenship behavior).

But in broad outline OCB can be defined as free employee behavior, such as helping other employees, voluntarily promoting their organization, which is an important factor to see the performance of the organization [28].

OCB itself has indicators including [27]:

a) Altruism, discretionary behavior to help others specifically to relevant tasks.

b) Sportmanship, the willingness of employees to tolerate less than ideal conditions without complaints.

c) Civic Virtue, individual behavior that shows that he is an individual who participates deeply and is responsible, such as being involved in, or caring about the state of the organization.

d) Conscientiousness, discretionary behavior of employees that goes well beyond the minimum role in the organization, obeying rules, attendance, rest, and so on.

e) Courtesy, discretionary behavior in individuals that aims to prevent the occurrence of problems related to work with others. 


\section{Religiosity and $O C B$}

The relevance of religiosity to OCB can be seen from research which shows that intrinsic religious factors (the emotional connection of individuals with religious values) have more influence on OCB than extrinsic religious factors (only carrying out religious activities for their own benefit) [18]. But in this study, researchers looked at religiosity factors in general. Therefore, researchers want to see the influence of each of the dimensions that exist in religiosity [29]. So the hypothesis in this study on figure 1 are:

H1 Dimension of participation has an influence on OCB.

H2 Dimension of importance has an influence on OCB.

H3 Dimension of meaning has an influence on OCB.

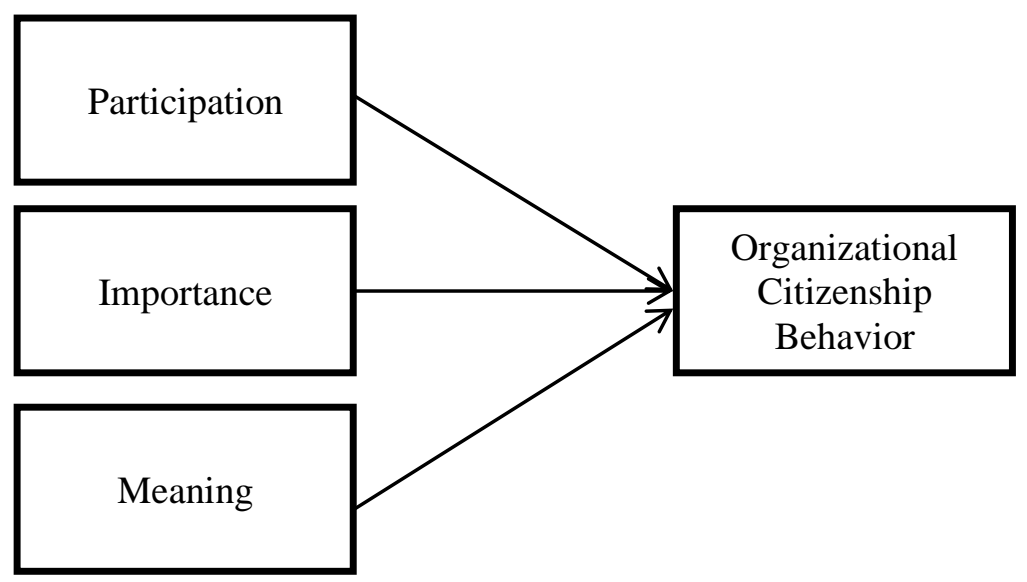

Fig 1.. Conceptual Framework

\section{METHODS}

This research was conducted in South Tangerang with a target population of student employees at tertiary institutions in South Tangerang. The approach used in this study is a quantitative approach to prove hypotheses with statistical analysis. Judging from the type of this research is the type of correlational research, namely research that seeks to connect two or more variables based on facts that have occcurred through data collection, data processing, than analyzing and finally expalining.

The sampling method used is accidental sampling which is one of the nonprobability sampling techniques. The sample used in this study were 174 student employees. Profile of respondents can be seen in the table 1 . 
Table 1. Profile of Respondents

\begin{tabular}{|c|c|}
\hline Gender & Amount of Respondents \\
\hline Female & 115 \\
\hline Male & 59 \\
\hline Religion & Amount of Respondents \\
\hline Islam & 157 \\
\hline Protestant & 9 \\
\hline Catholic & 7 \\
\hline Hindu & 0 \\
\hline Buddhist & 1 \\
\hline Confucian & 0 \\
\hline Other & 0 \\
\hline
\end{tabular}

Data collection in this study used a questionnaire that developed a variable of religiosity totaling 9 items and OCB variables totaling 15 items. All research variables are measured using a Likert scale; where: 5 as strongly agree until 1 as strongly disagree. Data obtained from respondents, then processed using a tool that is SPSS ver 22. The analysis used in this research is multiple linear regression.

\section{RESULT AND DISCUSSION}

The research results directly present the data and results obtained from the study. This section only provides a narrative description of the results of the study without any interpretation or evaluation.In this part of the discussion, researcher interprets the meaning of the results of the study, both in accordance with expectations or not. Following are the results of his research.

Table 2. Correlation Model Summary

\begin{tabular}{|l|r|r|r|c|}
\hline Model & R & R Square & Adjusted R Square & $\begin{array}{c}\text { Std. Error of the } \\
\text { Estimate }\end{array}$ \\
\hline 1 & $.364^{\mathrm{a}}$ & .133 & .118 & 4.479 \\
\hline
\end{tabular}

a. Predictors: (Constant), PARTICIPATION, IMPORTANCE, MEANING

Table 2 explains the magnitude of the correlation / relationship (R) value of 0.364 and the coefficient of determination ( $\mathrm{R}$ square) of 0.133 . This shows that the influence of independent variables (Meaning, Importance and Participation) on related variables (OCB) is $13.3 \%$.

From the output of table 3 , it is known that the calculated $\mathrm{F}$ value $=8,732$ with a significance level of $0,000<0.05$, then the regression model can be used to predict the 
participation variable or in other words there is the influence of the Meaning (X1), Importance (X2) and Participation (X3) variable of the OCB variable (Y).

Table 3. ANOVA

\begin{tabular}{|ll|r|r|r|r|r|}
\hline Model & & Sum of Squares & df & Mean Square & F & Sig. \\
\hline 1 & Regressio & 525.550 & 3 & 175.183 & 8.732 & $.000^{\mathrm{b}}$ \\
& $\mathrm{n}$ & 3430.828 & 171 & 20.063 & & \\
& Residual & 3956.377 & 174 & & & \\
\hline
\end{tabular}

a. Dependent Variable: OCB

b. Predictors: (Constant), PARTICIPATION, IMPORTANCE, MEANING

While from table 3 it can be seen that the constant value (a) is 39,348 while the Participation value (b / regression coefficient X1) is 0.794 , the Importance Value (b / regression coefficient X2) is -0.01 , and the Meaning value (b / regression coefficient $\mathrm{X} 3$ ) equal to 0.729 , so the regression equation can be written:

$$
\begin{gathered}
Y=a+b X 1+b X 2+b X 3, \text { or } \\
Y=39,348+0.794 X 1-0,001 X 2+0.729 X 3
\end{gathered}
$$

The equation can be translated as follows:

1. A constant of 39,348 implies that the consistent value of the variable Religiosity is equal to 39,348 .

2. Regression coefficient X1 of 0.794 states that for each addition of $1 \%$ OCB value, the Participation value increases 0.794 . The regression coefficient is positive. So that it can be said that the direction of the influence of variable X1 on $\mathrm{Y}$ is positive.

3. Regression coefficient $\mathrm{X} 2$ of $-0,001$ states that for each addition of $1 \%$ OCB value, the importance value decreases 0.001. The regression coefficient is negative. So it can be said that the direction of the effect of variable X2 on Y is negative.

4. Regression coefficient X3 of 0.729 states that for each addition of $1 \%$ OCB value, the Meaning value increases 0.729 . The regression coefficient is positive. So it can be said that the direction of the influence of the X3 variable on $\mathrm{Y}$ is positive.

From the output above, it is known that:

H1. Variable X1 (Participation) has a calculated $\mathrm{T}$ value $=3.306$ with $\mathrm{a}$ significance level of $0.001<0.05$. Then the regression model can be used to predict the participation variable or in other words the Participation variable (X1) influences the OCB variable (Y). 
H2. Variable X2 (Importance) has a calculated T value of -0.04 with a significance level of $0.997>0.05$. Then the regression model can be used to predict the participation variable or in other words the Importance variable (X2) does not affect the OCB variable (Y).

H3. Variable X3 (Meaning) has a calculated $\mathrm{T}$ value of 2.856 with a significance level of $0.005<0.05$. Then the regression model can be used to predict the participation variable or in other words the Meaning variable (X3) influences the OCB variable $(\mathrm{Y})$.

\section{CONCLUSION}

This section concludes that partially the Participation variable (X1) has a positive influence on the OCB variable (Y). If there is an increase in the Participation aspect, OCB will also increase. The variable Importance (X2) has no influence on the OCB variable (Y). If there is an increase in the aspects of importance, OCB has no influence from the increase, it could be decreased. The Meaning variable (X3) has a positive influence on the OCB variable (Y). If there is an increase in the Meaning aspect, then OCB also increases.

Simultaneously the variables Participation (X1), Importance (X2), and Meaning (X3) have an influence on the OCB variable (Y). If there is an increase in the aspects of participation, importance and meaning, then the OCB also increases. The results of this study are same as the research which shows that religiosity can be used to predict employees at UIN Sultan Syarim Kasim [30], public universities in Malaysia [31] and social workers in Muslim countries [32]. In fact, it is also necessary for organizations to accommodate religious activities to inculcate religiosity, which turns out to be able to expedite and streamline the functioning of the organization itself [33].

Briefly the results and discussion of the study. This section also explains the implications of the results, limitations of the study and recommendations for the development of future research.

\section{REFERENCES}

[1] M. Pavalache-Ilie, Organizational Citizenship Behavior, Work Satisfaction and Employees' Personality, Procedia - Social and Behavioral Sciences 127, 2014, pp. 489493.

[2] G. Günay, Relationship between Job Satisfaction, Organizational Citizenship Behavior and Employee Performance: Sample of Edirne Financial Office Employees in Turkey. American International Journal of Contemporary Research 8:1, 2018, pp. 64-74.

[3] R. Gultom, N. Erdiana, R. Nofrianda, Hubungan antara Kepuasan Kerja dan Komitmen Organisasi terhadap Organiational Citizenship Behavior pada Karyawan, Psyche 165 13:1, 2020, pp. 67-71. 
International Journal Of Science, Technology \& Management

[4] S. Widodo, A. Ramadhanu, Organizational Citizenship Behavior (OCB) ditinjau dari Kepuasan Kerja Intrinsik, Jurnal Penelitian dan Pengukuran Psikologi 4:1, 1-6.

[5] Z. Scola, C. Schaeperkoetter, L. Lower, J. Bass, "It's just something engrained in them": examining Organizational Citizenship Behaviors within Part-time Campus Recreation Center Employees, Managing Sport and Leisure, 2017, pp. 1-17.

[6] M. Awuni, M. Tanko, Organizational Citizenship Behavior and Religiosity at the Workplace, International Journal of Contemporary Research and Review 10:5, 2019, pp. 21501-21514.

[7] M. Yaqin, I. Thohari, F. Mustafida, Prestasi Mahasiswa Pekerja di Fakultas Agama Islam Universitas Islam Malang, Vicratina 5:1, 2020, pp. 61-69.

[8] C. LeBlanc, Characteristics Shaping College Student Organizational Citizenship Behavior, American Journal of Business Education 7:2, 2014, pp. 99-108.

[9] D. Kusumajati, Organizational Citizenship Behavior (OCB) Karyawan pada Perusahaan, Humaniora 5:1, 2014, pp. 62-70.

[10] Wahyudin, L. Pradisti, S. Wulandari, Dimensi Religiusitas dan Pengaruhnya terhadap Organizational Citizenship Behaviour (Studi pada Universitas Jenderal Sodirman Purwokerto), Jurnal Ekonomi, Bisnis, dan Akuntansi (JEBA) 20:3, 2018, pp. 1-14.

[11] Y. Siswanti, A. Haryadi, Peran Kepuasan Kerja dalam memediasi pengaruh Religiusitas terhadap Organizational Citizenship Behavior (OCB) (abstract only), Forum Manajemen Indonesia (FMI) 9, 2017, pp. 36.

[12] H. Astuti, H. Sulistyo, The Role of Religiusity and Person on Fit (PO) to Improve Organizational Citizenship Behavior (OCB), International Jurnal of Islamic Business Ethics (IJIBE) Special Issue, 2017, pp. 234-245.

[13] A. Budhiarti, Y. Nisa, The Effect of Religiusity, Transformational Leadership, and Demography on Organizational Citizenship Behavior (OCB), JP3I 4:2, 2017, pp. 101116.

[14] I. Noble, Contemporary Religiosity and the Absence of Solidarity With Those in Need, Journal of Nationalism, Memory \& Language Politics 13:2, 2019, pp. 224-238.

[15] N. Mahudin, N. Noor, M. Dzulkifli, N. Janon, Religiosity among Muslims: A Scale Development and Validation Study, Makara Hubs-Asia 20:2, 2016, pp. 109-121.

[16] Z. Zimmer, F. Rojo, M. Ofstedal, C. Chiu, Y. Saito, C. Jagger, Religiosity and Health: A Global Comparative Study, SSM-Population Health 100322, 2019.

[17] H. Pelani, B. Rama, W. Naro, Kegiatan Keagamaan sebagai Pilar Perbaikan Perilaku Narapidana di Lembaga Pemasyarakatan wanita Kelas IIA Sungguminasa Gowa, Jurnal Diskursus Islam 6:3, 2018, pp. 444-458.

[18] E. Olowookere, K. Oguntuashe, O. Adekeye, Relationship between Religiosity and Citizenship Behaviors in Organizations: Empirical Evidence from Selected Organisations in Lagos State, Mediterranean Journal of Social Sciences 7:4, 2016, pp. 475-484.

[19] A. Shtulman, M. Rattner, Theories of God: Explanatory coherence in Religious Cognition, PloS ONE 13:2, 2018, pp. 1-17.

[20] F. Pari, Pengalaman Rasional Eksistensi Tuhan: Pengantar Ontoteologi, Kanz Philosophia 1:1, 2011, pp. 111-128. 
International Journal Of Science, Technology \& Management

[21] Shodiq, Pengukuran Keimanan: Perspektif Psikologi, Nadwa: Jurnal Pendidikan Islam 8:1, 2014, pp. 125-138.

[22] J. Dezzuter, S. Casalin, A. Wachholtz, K. Luyckx, J. Hekking, W. Vandewiele, Meaning in Life: An Important Factors for the Psychological Well-Being of Chronically Ill Patients?, Rehabilitation Psychology 58:4, 2013, pp. 334-341.

[23] F. Martela, M. Steger, The three Meanings of Meaning in Life: Distinguishing coherence, purpose and significance, The Journal of Positive Psychology 11:5, 2016, pp. 1-15.

[24] V. Hidayat, Kebermaknaan Hidup pada Mahasiswa Semester Akhir, Jurnal Psikologi Integratif 6:2, 2018, pp. 141-152.

[25] T. Bateman, D. Organ, Job Satisfaction and the Good Soldier: The Relationship between Affect and Employee "Citizenship", The Academy of Management Journal 26:4, 1983, pp. 587-595.

[26] D. Organ, Organizational Citizenship Behavior: It's construct Clean-up Time, Human Performance 10:2, 1997, pp. 85-97.

[27] P. Podsakoff, S. MacKenzie, J. Paine, D. Bachrach, Organizational Citizenship Behaviors: A Critical Review of the Theoretical and Empirical Literature and Suggestions for Future Research, Journal of Management 26:3, 2000, pp. 513-563.

[28] K. Rose, A. Herd, S. Palacio, Organizational Citizenship Behavior: An Exploration of One Aspect of Cultural Adjustment Faced by U.S. Army Soldiers Transitioning from Military to Civilian Careers, Advances in Developing Human Resources 19:1, 2017, pp. 14-24.

[29] Y. Ariyanti, The Effect of Religiosity on Organizational Citizenship Behaviour (A Case Study on Teachers of Roudlotus Saidiyyah Foundation), Advanced in Social Science, Education and Humanities Research (ASSEHR) 140, 2017, pp. 192-194.

[30] R. Susanti, Hubungan Religiusitas dan Kualitas Kehidupan Kerja dengan Organizational Citizenship Behavior (OCB) pada karyawan, Jurnal Psikologi 11:2, 2015, pp. 94-102.

[31] N. Ramlee, A. Osman, S. Salahudin, S. Yeng, S. Ling, M. Safizal, The Influence of Religiosity, Stres and Job Attitude towards Organizational Behavior: Evidence from Public Universities in Malaysia, Procedia Economics and Finance 35, 2016, pp. 563573.

[32] H. Abdelnaiem, Islamic Religiosity, Work Pressures, and Organizational Behavior of Social Workers, Scholars Journal of Arts, Humanities and Social Sciences 6:9, 2018, pp. 1786-1797.

[33] L. Asamani, A. Mensah, Religiosity as an Antecedent of Employees' Organizational Citizenship Behavior, Advanced in Social Sciences Research Journal 3:7, 2016, pp. 3445 . 